\title{
Umwelt ethics
}

\author{
Morten Tonnessen \\ Dept. of Philosophy, University of Oslo \\ Elvetun, Rovenveien 116, N-1900 Fetsund, Norway \\ e-mail: morten@villamer.org
}

\begin{abstract}
In this paper I will sketch an Umwelt ethics, i.e., an ethics that rests heavily on fundamental features of Jakob von Uexküll's Umwelt theory. In the course of an interpretation of the Umwelt theory, a number of concepts are introduced. These include ontological niche, common-Umwelt, total Umwelt and bio-ontological monad. I then present an Uexküllian reading of the deep ecology platform. It is suggested that loss of biodiversity, considered as a physio-phenomenal entity, is the most crucial aspect of the ecological crisis, which can be understood as an ontological crisis.
\end{abstract}

The well-being and flourishing of human and non-human life on Earth have value in themselves.

Næss 1993: 197

Das gesamte Universum, das aus lauter Umwelten besteht, wird durch die Funktionskreise zusammengehalten und nach einem Gesamtplan zu einer Einheit verbunden, die wir Natur nennen.

Uexküll 1928: 221

An Umwelt ethics can be vaguely defined as an ethics that rests heavily on fundamental features of Jakob von Uexküll's Umwelt theory. Admittedly, in principle there can be several, conflicting Umwelt ethics. My approach will be to sketch an ethics that, in addition to the Umwelt theory, draws from deep ecology, as advocated by Arne Næss (e.g., Næss 1989). The outcome will be an Uexküllian 
interpretation or specification of The Deep Ecology Platform (Næss 1993: 197).

By the Umwelt theory, I understand Uexküll's thinking on the nature of signs, phenomena and living beings, as expressed in texts such as Umwelt und Innenwelt der Tiere (1909; 1921), Theoretische Biologie (1920; 1928; cf. 1926), Streifzüge durch die Umwelten von Tieren und Menschen (Uexküll, Kriszat 1956 [1934]; cf. Uexküll 1992) and Bedeutungslehre (Uexküll, Kriszat 1956 [1940]; cf. Uexküll 1982). "The expanded Umwelt theory" might be a more appropriate designation (a more refined classification of Uexküll's philosophically infected biological thinking is found in Pobojewska 1993a; 1993b). Furthermore, one might say that rather than simply interpreting the Umwelt theory, I elaborate some of Uexküll's ideas. If so, my use of Uexküll's ideas can be termed The Umwelt ontology (cf. Tønnessen 2001; 2002: 9-12, 50-53).

Whereas the Umwelt ontology and its application in a reading of the deep ecology platform will be the subject of the second part of this paper, the first will be devoted to the biosemiotic and historical context of Umwelt ethics. It will encompass a review of biosemiotics and the environmental crisis, Jesper Hoffmeyer's justification of attributing moral status and Uexküll's dealings with ethical and political matters.

A common view amongst biosemioticians seems to be that the ecological crisis can be regarded as a large-scale, real-life falsification of mechanist, reductionist biology. Or, if that is too bold a statement, at least there is not much doubt, in the mind of biosemioticians, that the success of such a scientific program is one of the reasons why the crisis has escalated. Thure von Uexküll, for example, claims that it is the predominant scientific thought that has lead us to bring nature into its present desolated state (J. v. Uexküll 1980: back page) ${ }^{1}$. Jesper Hoffmeyer (1993: 162) similarly conceives of the common scientific view as "a paradigmatic view of nature which supports the rationality

He comments on "der modernen Naturwissenschaft [...] und die damit verbundene Geisteshaltung [...] die dazu geführt hat, daß wir unsere Welt in kaum hundert Jahren in einen so desolaten Zustand gebracht haben". 
of that homogenizing and simplifying human practice which is the very core of the ecological crisis". "While nobody should deny the triumphs of the reductionist program in science", he claims, "it has become increasingly visible that big, important, and perhaps chronic lacunas remain in the epistemological basis of modern civilization" (Hoffmeyer 1993: 153-154). Luis Emilio Bruni (2001: 294), as well, considers the ecological crisis mainly an epistemological crisis. He regards the ecological crisis as the logical outcome of "mechanistic biology, genetic reductionism, economical determinism and neoDarwinian cultural and biological perspectives" (Bruni 2001: 298299).

As Riste Keskpaik (2001: 313) observes, "in the context of the deepening environmental crisis [...] a semiotic approach opens a new perspective for identifying the origin of the problem in our mind/culture rather than in nature". In line with common bio- and ecosemiotic thought, Winfried Nöth (2001: 76) holds that the roots of the ecological crisis "are in a Cartesian dualism between culture and nature, which has opposed humans to the rest of the natural world for centuries". Referring to "the manifest failures of action taken within the existing rubric of scientific, technological, economic, and political rationality", Max Oelschlaeger (2001: 220) claims that ecosemiotics, the study of sign processes that relate organisms to their natural environment (Nöth 2001: 71), can "facilitate the sustainability transition" (Oelschlaeger 2001: 220).

In spite of this seemingly widespread eco-political motivation, not many biosemioticians have dealt explicitly with topics of normative ethics. Kalevi Kull, in "Biosemiotics and the problem of intrinsic value of nature", is primarily concerned with descriptive ethics, establishing that "the origin of value can be seen as a problem of [...] biosemiotics" (Kull 2001: 355). In an interesting passage, however, he notes that "the necessary turn to a biocentric view [...] may mean that the valuing process is extended so that the experiential world of any living being is included" (Kull 2001: 356).

\section{Signs of value in the biosphere: Hoffmeyer}

The first systematical exploration of biosemiotics' relevance for environmental ethics is found in Jesper Hoffmeyer's 1993 article "Biosemiotics and ethics" (cf. Hoffmeyer 1996: 129-146). He argues 
(1993: 173) that by admitting interpretative processes to be a core phenomenon of life in general, one can reach the conclusion that living creatures should be considered as moral subjects, i.e., subjects that deserve moral consideration.

Hoffmeyer's justification of the attribution of moral status is inspired by the Norwegian philosopher Jon Wetlesen, for whom Spinoza's definition of subjecthood acts as a point of departure. According to Spinoza (1951: Pt. III, Prop. IV), "everything, in so far as it is in itself, endavours to persist in its own being". Wetlesen (1993) argues that all non-human individual organisms and supra-individual wholes that resembles moral agents by showing self-determination, or striving, can be regarded as subjects with a moral standing. Hoffmeyer's equivalent of the Spinozean perseverance is his own concept codeduality (Hoffmeyer 1993: 165). Organic code-duality, a property common to all living beings, can be understood as the semiotic interplay between the analog (cell) and digital (DNA) versions of a living being (cf. Hoffmeyer 1996: 44). In conclusion (Hoffmeyer 1993: 173), “all living systems deserve to be considered as moral subjects, but some of them more so than others". As a parameter that might eventually be used for grading among moral subjects, he suggests semiotic freedom, i.e., the level of richness or depth of meaning that a being is able to communicate. Hoffmeyer (1993: 172; cf. 1996: 139) attributes true subjectivity, and, consequently, moral status, at the individual level to all animals possessing a complex nervous system. Primitive organisms, on the other hand, such as amoebas or mealworms, are moral subjects only at species level.

A premise for this judgment is that human beings are "perfectly capable of identifying with any entity that might occupy positions similar to those we occupy ourselves in the bio-logics of nature" (Hoffmeyer 1993: 172). In Hoffmeyer's interpretation, this means that we are capable of identifying with "umwelt-builders in the broadest sense of this term, i.e. even species of lower level organisms lacking neural systems but which, qua species, nevertheless create a kind of (genomic) umwelt through their evolutionary incorporation of ecological niche conditions into the future" (Hoffmeyer 1993: 172). ${ }^{2}$

2 As this passage exemplifies, Hoffmeyer departs from Uexküll's understanding of the Umwelt concept. In an Uexküllian setting, it makes no sense to talk about "genomic Umwelten", since each and every Umwelt is in fact the privilege of the subject in question. Consequently, although evidently founded on biosemiotics, Hoffmeyer's ethics cannot be regarded an Umwelt ethics. 
While Hoffmeyer (1993: 172, cf. 1996: 133) explicitly adopts Næss' definition of identification, his usage of the term is not by far as flexible as Næss'. Næss (1990) defines an identification process as 'a process whereby another being's interests are instinctively responded to as though they were one's own interests". Næss explains:

Through identification, higher level unity is experienced: from identifying with 'one's nearest', higher unities are created through circles of friends, local communities, tribes, compatriots, races, humanity, life, and, ultimately, as articulated by religious and philosophical leaders, unity with the supreme whole, the 'world' in a broader and deeper sense than the usual. (Næss 1985: 260)

Although he admits that mountains are not alive in a strict scientific sense, Næss himself claims that he identifies with Hallingskaret, where he has a cottage. Identification, as Næss conceives of it, has no natural barrier, and is not an inter-subjective, but a subjective phenomenon.

To Hoffmeyer's credit, his criterion for deciding which entities we are capable of identifying with is so vague that it allows for a certain flexibility. This vagueness, or flexibility, however, is not mirrored in his conclusion. If we are capable of identifying with any entity that might occupy positions similar to those we occupy ourselves in the bio-logics of nature, then why not a mountain, or an individual mealworm? And, more generally: if interpretative processes are to form the basis of attribution of moral status, why should code-duality be considered the relevant property? In what way is organic codeduality related to the actual well-being of a creature or a living system, in the same sense as self-determination or perseverance is?

\section{Uexküll and the German morals}

Before I turn to the Umwelt ethics and its foundation in the Umwelt theory, I will give a brief account of Uexküll's personal ethical and political views. Noteworthy, only in one sense can Umwelt ethics be said to be an ethics in the spirit of Uexküll: namely, that it is founded on an interpretation of the Umwelt theory.

Baron Jakob von Uexküll was a true aristocrat. In Staatsbiologie (Uexküll 1920: 18), he argues, by way of biological analogies, that the monarchy is the only natural form of government. In contrast, the idea 
of democracy is just as absurd as if "in our body [...] the majority of the body's cells were to decide in place of the cortical cells, which impulse the nerves should transmit" (Uexküll 1920: $46^{3}$; translated in Harrington 1999: 59). One month after the declaration of the democratic Weimar Republic, Uexküll wrote, in a private letter to race philosopher Houston Stewart Chamberlain, that a revolution "is always cancer, that is, the growth of individual cells, and the destruction of the organs that goes hand in hand with that" (translated in Harrington 1999: $58^{4}$ ). In another private letter to Chamberlain, Uexküll summarized what he conceived of as the greatest threats of the time in two sentences: "When the machine rules, the personality perishes. The bolsheviks have no personality, nearly all of them are soulless jews". 5 Needless to say, anti-semitism has no place in the Umwelt ethics that is the topic of this paper. An account of Uexküll's views on The Weimar Republic, jews and national socialism is found in Harrington (1999: 35-71).

In "Darwin und die englische Moral", the only text to my knowledge in which he deals explicitly with animal ethics, Uexküll (1917) contrasts the German morals with the English, and Kant's example with Darwin's. "The German imperative of Kant", Uexküll holds (Uexküll 1917: 225, ${ }^{6}$ translated in Harrington 1999: 55), "requires every individual to be an autonomous lawgiver on moral issues". In contrast, the ethics propagated by Darwin, and typical for the English, rests on the social mechanism of praise and criticism ("Lob" and "Tadel").

According to Darwin (1882), in the course of cultural development, man's moral sensitivity is refined, so as to embrace an everexpanding group of human subjects, eventually even animals. "Darwin's position", Uexküll comments, "can be briefly summarized in the

3 "Es ist somit ein Zustand eingetreten, der auch in unserem Körper eintreten würde, wenn an Stelle der Großhirnzelle die Mehrzahl der Körperzellen zu beschließen hätte, welche Impulse den Nerven zu übermitteln sind" (Harrington 1999: 231).

4 "[Revolutionen] ist immer Krebs, d.h. das Wuchtern der Einzelzellen und damit Hand in Hand gehend die Zerstörung der Organe" (Harrington 1999: 230).

5 Partly my translation. "Wenn die Maschine regiert, geht die Persönlichkeit zugrunde. Die Bolschewisten haben keine Persönlichkeit, sie sind fast alle seelenlose Juden" (Harrington 1999: 65, 233).

6 "Der deutsche Imperative Kants macht jeden Einzelnen zum selbstherrlichen Gesetzgeber im moralischen Dingen." 
following way: The bigger the herd, the higher the morality". ${ }^{7} \mathrm{He}$ claims:

It is not, as Darwin holds, an artificial barrier that is an impediment to the extension of moral consideration to all peoples and to the animals, rather, the ethics that is founded on praise and criticism is itself the barrier for the extension to fellow creatures whose praise and criticism one neither hears nor takes any note of. (Uexküll 1917: 224)

Unfortunately, Uexküll does not suggest an alternative strategy of justification, nor does he discuss whether attribution of moral status to animals is possible within a Kantian framework (cf. Kant 1997).

\section{II}

\section{The Umwelt ontology — a conceptual framework}

An ontological subject can be defined as someone for which something appears. According to the Umwelt theory, all reality is subjective appearance (1928: 2), and - as Thure von Uexküll (1992: 285) formulates it - "all living organisms, including cells, behave as subjects, responding only to signs and - for as long as they live - not to causal impulses". Through semiotic agency, all living beings are sign utilizers, and therefore ontological subjects, i.e., subjects of the phenomenal world.

However, while Uexküll (1928: 62) clearly states that all living beings are surrounded by an individual phenomenal world, it should be noted that the statement quoted in the motto of this paper is not really accurate. Phrased in modern terminology, Umwelten can be attributed to protists, bacteria and animals (including the animal that does not want to be an animal, i.e., man), but not to plants and fungi (Uexküll, Kriszat 1956 [1940]: 111). Instead, they have Wohnhüllen,

7 "Darwins Standpunkt kann man kurz dahin zusammenfassen: Je größer die Herde, um so höher die Moral" (Uexküll 1917: 223, translated in Harrington 1999: 55).

8 My translation. "Es ist keine künstnerliche Schranke, wie Darwin meint, die sich der Ausbreitung seiner Moral auf alle Völker bis auf die niederen Tiere in den Weg stellt, sondern die Moral, die sich auf Lob und Tadel aufbaut, ist selbst die Schranke für die Ausbreitung über Mitgeschöpfe, deren Lob und Tadel man weder hört noch beachtet." 
in which the objects of Umwelten are replaced by meaning-factors. These must, along with Umwelten, be understood as a category of individual phenomenal worlds. ${ }^{9}$ While only Umwelt-carriers take part in functional cycles, plants and fungi, as well, partake in contrapuntal relations, i.e., subject-object-relations characterized by a mutual correspondence between the two entities. There are at least two kinds of contrapuntal relations: Relations between two meaning-utilizers (e.g. a flower and a bee, or a predator and its prey), and, more generally, relations between a meaning-utilizer and a meaning-carrier or meaning-factor in its phenomenal world (e.g., an eye and the sun). Functional cycles can be regarded as special cases of contrapuntal relations. The known phenomenal world, therefore, consists of Umwelten and Wohnhüllen that, through the interconnectedness that the various contrapuntal relations result in, comprise what we call nature.

In this intricate web - of life, of semiosis, of world - we occupy an ontological niche. The ontological niche of a being can be defined as the set of contrapuntal relations that it takes part in at a given point of natural history. ${ }^{0}$ The ontological niche of a being delimits the "area" that this being occupies in the phenomenal world. Simultaneously, through its ontological niche, the phenomenal world of a being is intertwined with other phenomenal worlds, thus integrating this being into the society of phenomenal subjects.

Although the diverse phenomenal worlds at some points are intertwined, each and every individual phenomenal world remains the property of the subject in question, and its phenomena appears to this being only. In case of contrapuntal relations between two meaningutilizers, each of the two subjects appear as an object or factor in the phenomenal world of the other, but they don't share phenomena. This holds true for human beings as well. However, while one cannot share Umwelt, one can take part in a common-Umwelt. ${ }^{11}$ By a common-

9 Cf. Uexküll, Kriszat 1956 [1940]: 111: "Die Pflanze begegnet den äußeren Wirkungen nicht mit Hilfe von rezeptorischen oder effektorischen Organen, aber dank einer lebenden Zellenschicht ist sie befähigt, aus ihrer Wohnhülle die Reizauswahl zu treffen."

10 Cf. Hoffmeyer (1996: 140): "The character of the animal's umwelt is what defines the spectrum of positions that an animal can occupy in the bio-logical sphere, its semiotic niche".

11 Cf. Hoffmeyer (1996: 112): "Through speech, human beings broke out of their own subjectivity because it enabled them to share one large, common umwelt". 
Umwelt, I understand a particular part of a group of Umwelten, belonging to a group of subjects that have certain schemata in common. In these Umwelten, the same kind of perceptual or conceptual objects appear to the subjects as the same kind of meaningful objects. One example of common-Umwelten is Umwelten of professions ("Berufsumwelten"; cf. Uexküll 1910: $126^{12}$ ).

A different type of abstract phenomenal entities can be termed total Umwelten. By a total Umwelt, I understand the sum total of the manifold phenomena appearing in the Umwelten of a particular group of subjects. An example that is mentioned by Uexküll (1928: 181) is the total Umwelt of a species. ${ }^{13}$

Noteworthy, according to Uexküll, the subject and its phenomenal world are not separate entities, but, as illustrated by the functional cycle, together make up one unit. ${ }^{14}$ One could call this belief ontological holism. To signify this unified entity, Friedrich Brock (1934) introduced the term "Tier-Umwelt-monade". However, Uexküll's ontological holism is not restricted to Umwelt-carriers, and I therefore suggest to replace Brock's term with the more general expression bioontological monad (for my usage of the term "bio-ontology", see Tønnessen 2001: 684). While a bio-ontological monad is a being and its subjective world considered as a inseparable whole, the expression bio-ontological entity can be taken to designate, even more generally, the union of a biological entity and its phenomena, or - in the case of lower level entities - signs. Relevant biological entities are cells, organs (lower level entities), species, ecosystems and the biosphere (higher level entities). The phenomenal counterpart to the biosphere, i.e., the sum total of all living beings of Earth, is the known phenomenal world. Taken as a bio-ontological entity, it represents the inseparable whole of life and world. In lack of a better designation, it might be called the bio-phenomenal sphere.

12 "In ihm Gegenstände unterschieden werden, die anderen Berufsklassen ganz gleichartig erscheinen".

13 "Wenn wir die Funktionskreise aller Einzelwesen einer Art zusammenbauen könnten, so würden wir die gemeinsame Umwelt der ganzen Art enthalten, und diese würde entsprechend den Abweichungen der Einzelwesen größer und reicher sein als die Umwelt der einzelnen."

14 Uexküll (1909: 196) holds that "die Natur und das Tier, nicht wie es den Anschein hat, zwei getrennte Dinge ist, sondern daß sie zusammen einen höheren Organismus bilden. [...] Die Umwelt, wie sie sich in der Gegenwelt des Tieres spiegelt, ist immer ein Teil des Tieres selbst, durch seine Organisation aufgebaut und verarbeitet zu einem unauflöslichen Ganzen mit dem Tiere selbst." 
Even though human beings are bio-ontological monads like everybody else, we do possess some distinctive features. In an Uexküllian language, these can be summarized in seven points.

1. Humans are capable of perceiving their own actions. This has the effect that in the case of human Umwelten, Merkwelt and Wirkwelt are not clearly separated entities (cf. Uexküll 1922: 181).

2. The number of schemata that a human operates with is flexible and has potential to grow as it gets familiar with, or invents, new objects.

3. Human Umwelten are characterized by a high level of individuality. This has the effect that one human Umwelt can differ substantially from another.

4. Participation in different common-Umwelten (cultures, subcultures) are of crucial importance to human Umwelt experience.

5. In addition to the four main types of functional cycles (cf. Uexküll 1928: 101), humans engage in specifically human functional cycles. One of these is the functional cycle of the moral subject.

6. Every human has, as part of its Umwelt, a conceptual world, incorporating concepts of language as well as, in a vaguer sense, concepts, simple or complex, of art, religion etc. The conceptual world has its roots in sensory perception, and its concepts are meaningful only by reference - direct or indirect - to concrete objects of perception (cf. Uexküll 1928: 334-340).

7. The perceptual objects of humans are under most circumstances colored, imprinted and structured by various concepts. Consequently, humans can be said to have a conceptionalized Umwelt experience.

\section{Deep ecology}

The deep ecology platform was originally formulated by Arne Næss and George Sessions in the mid-eighties. ${ }^{15}$ In one of its versions, it reads:

1. The well-being and flourishing of human and non-human life on Earth have value in themselves (synonyms: intrinsic value, inherent worth).

15 Although Næss (1936, cf. particularly 64-70) makes use of the Umwelt theory in his doctoral thesis, he has not, to my knowledge, referred to Uexküll in the context of deep ecology. 
These values are independent of the usefulness of the non-human world for human purposes.

2. Richness and diversity of life forms contribute to the realization of these values and are also values in themselves.

3. Humans have no right to reduce this richness and diversity except to satisfy vital needs.

4. The flourishing of human life and cultures is compatible with a substantially smaller human population. The flourishing of non-human life requires a smaller human population.

5. Present interference with the non-human world is excessive, and the situation is rapidly worsening.

6. Policies must therefore be changed. These policies affect basic economic, technological, and ideological structures. The resulting state of affairs will be deeply different from the present.

7. The ideological change will be mainly that of appreciating life quality (dwelling in situations of inherent value) rather than adhering to an increasingly higher standard of living. There will be a profound awareness of the difference between bigness and greatness.

8. Those who subscribe to the foregoing points have an obligation directly or indirectly to try to implement the necessary changes.

(Næss 1993: 197)

\section{Biosemiosis and the well-being and flourishing of life}

In a biosemiotic context, a moral agent can be defined as someone who stands for itself as one who is required to act according to certain moral standards, i.e., a being who takes part in the functional cycle of the moral subject. When this functional cycle comes into use, the moral subject, i.e., the object in the subject-object relation, has a moral tone. In other words, the moral agent experiences a call for moral treatment. The object in question can be concrete or abstract, a particular being or living system that is encountered by the moral agent, or an abstract (though real, ontological) entity, such as "wolves", "nature", "life".

According to Næss (1993: 198), the first point in the deep ecology platform "refers to the biosphere, $[. .$.$] individuals, species, popula-$ tions, habitat, as well as human and non-human cultures". Næss also mentions landscapes and ecosystems. Given an Uexküllian framework, all of these must be understood as bio-ontological entities. A culture, for example, can be defined as a certain common-Umwelt that allows for a certain total Umwelt. The fact that the flourishing of human life rests on the flourishing of concepts should result in politi- 
cal and cultural tolerance. As for ecosystems and inhabited landscapes, one could probably reach a bio-ontological definition by way of the concepts of contrapuntal relations and total Umwelt. A habitat might be regarded as the subjective space, or perhaps Heimat (home), of an individual or population.

The reason why it makes sense to regard all semiotic agents, i.e., bio-ontological monads, as moral subjects, is that in respect to these entities, our actions make a difference. Only for semiotic agents can our actions ultimately appear as signs that influence their well-being. In capacity of meaning-utilizers, all semiotic agents, be it the simplest creature, are able to distinguish between what they need and what is irrelevant or harmful to them. As Kull (2001: 361) says: "Everything alive has needs per se, not so the lifeless nor the dead". Wherever there is semiosis, there are needs, and even though actual moral treatment is also a question of practicability, attribution of moral status is a principal one.

But why regard higher-level bio-ontological entities as moral subjects? Because a living being is not an isolated incident. In a profound sense, a subject is what it relates to. The contrapuntal relations that it takes part in do, largely, define what being this subject is all about. The individual self branch off into the society of phenomenal subjects and into the phenomenal world, it is already social, already worldly, already more-than-individual. You cannot really value a subject without at the same time valuing the web of contrapuntal relations that it takes part in.

\section{Biological, i.e. physio-phenomenal, i.e. behavioural diversity}

The second point has one empirical and one normative element. First, that "life itself, as a process over evolutionary time, implies an increase of diversity and richness" (Næss 1993: 198), and second, that the diversity and richness of life forms have value in themselves. In the context of an Uexküllian ethics, diversity of life forms reads as physiological and phenomenal diversity, and is accompanied by behavioural diversity. This interpretation is consistent with Uexküll's statement (1928: 198) that each appearing functional cycle (understood as a steady, vital contrapuntal relation between two subjects, or a subject and an object, that has not previously been connected) founds a new animal species. The belief that not only living beings or 
systems have value in themselves, but also the diversity and richness of life forms, stresses the value of the flourishing of the bio-phenomenal sphere, a flourishing of life and world alike.

\section{Vital needs - or: Can one eat a moral subject?}

The third point states that humans have no right to reduce the richness and diversity of life except to satisfy vital needs. In light of the value of the individual beings' flourishing and well-being, it is reasonable to interpret this principle as valid both on an individual and an ecological level, relevant for animal ethics as well as eco-ethics. What counts as a vital need, however, remains to be specified. At the ecological level, human interference with the ontological niches of other species and populations could serve as a starting point. Human societies have no right to disturb those of the contrapuntal relations of other life forms that are vital for the survival of a species or a population, except for the sake of cultural survival.

On the individual level, the actual moral judgment will probably rely on the moral agent's empathy or ability to identify with others, and what counts as a vital need will be interpreted in this context. As your empathy grows, or comes into use, you realize that there are habits you can do without. I, for my part, am liable to state: the greater the empathy, the better - as long, that is, as it is compatible with ones' own well-being.

Empathy with animals might lead to vegetarianism, which in most cases must be considered to be compatible with satisfying one's own vital needs. However, vegetarians, and especially radical ones, such as vegans, might face some paradoxes. For example: In a world of vegans - with no animal products consumed nor produced - what would be the fate of domesticated animals? Many of them could not possibly survive on their own, since, in the course of breeding, man has become a vital counterpoint in their ontological niches. In a vegan world, we would be left with two alternatives: Either we could keep them in zoos or as a sort of pets, or we would have to let them go extinct. What the vegan should ask herself is: Is an animal that depends on human beings for its pure existence really better off not existing? If we chose the other alternative, the number of animals that we would be able to hold for the pure pleasure of their company would not be likely to even come close to the present number of 
domesticated animals. And if it did, the vegan society might end up being just as energy- and land-consuming as the present meat-based society, thus worsening the conditions for wild animals. The moral of the vegans paradox is that veganism motivated by the well-being of domesticated animals is likely to be mislead. A different motivation, such as opposition against excessive human interference with the animal kingdom, makes more sense.

\section{Population and diversity}

According to the fourth point, the flourishing of human life and cultures is compatible with a substantially smaller human population, whereas the flourishing of non-human life requires a decrease of the human population. The belief that even with a substantially smaller human population it is possible to preserve cultural diversity implies that a decrease of population is compatible with preservation or further development of human phenomenal and behavioural diversity. The richness, diversity and flourishing of the human total Umwelt is not dependent of the present population size.

\section{The ontological crisis and its cause}

The fifth point states that present interference with the non-human world is excessive, and that the situation is rapidly worsening. I find it appropriate to portray the ecological crisis as an ontological crisis, i.e., a crisis of the known phenomenal world characterized by a sudden, significant loss of phenomenal diversity. In this sense, the ecological crisis is truly a crisis of world scale - a world event indeed. Due to the complexity of the biosphere, and the ability of some creatures to survive under comparatively extreme conditions, there is not much chance that life as such will cease to exist in foreseeable future. So, it is not the end of the world. Nevertheless, it is the end of many a being's world. As life forms go extinct, so do their Umwelten or Wohnhüllen. The world is no longer perceived or approached in that way - or, as far as the phenomenal world is concerned, the world is no longer like that. The world has lost in richness. 
The present loss of physio-phenomenal diversity is the work of an ever-expanding economy that is complicating and simplifying by nature and in constant conflict with the complex structure of natural entities. "When the civilizing process extends to Nature's own 'selforganizing' systems," Claus Emmeche (2001: 247) notes, "it may have catastrophic consequences when another developmental logic is imposed on natural systems. Natural systems have natural barriers. The nature of capitalist civilization is breaking down all barriers for the sake of free exchange of 'goods' and resources." The latest manifestation of the centuries old growth economy is economic globalization, i.e., the drive toward global capitalism, "the ecosemiotic effect of which is to extend the symbolic domain of exchange value into new areas of the semiosphere" (Emmeche 2001: 242). Since globalization can also be depicted as "the transgressing expansion of the Western way of life" (Emmeche 2001: 242), cultural diversity is also at stake, thus adding to the loss of phenomenal and behavioural diversity (cf. Emmeche 2001).

The current trend towards loss of worlds is not likely to be reversed until some fundamental measures are taken. In the meantime, the policy of proponents of global capitalism, such as The World Bank, International Monetary Fund and World Trade Organization, should be resisted. Instead of adopting the Western model of development, it would be a positive contribution if emerging and transitional economies indulged in alternative models of development. So should the industrial countries.

\section{The watershed in human self-comprehension- or: Why I am not a revolutionary}

According to the sixth point of the deep ecology platform, policies that affect basic economic, technological and ideological structures must be changed, and the resulting state of affairs will be deeply different from the present. In one sense, there are no simple solutions, i.e., the changes will have to be fundamental and affect several aspects of modern society. In another sense, however, there is nothing but simple, i.e., non-complicated solutions. Whereas a "complex" technological approach will involve the usage of a manifold of small-scale, low-energy, non-hazardous technologies, technofixes will be out of the question. 
One recent proposal, endorsed by George W. Bush, is to inject carbon dioxide into oilfields, gasfields, coalbeds or deep saline aquifers, and store it underground. As Diss and Muttitt (2001: 28) note, "if it proves unsuccessful, after say a 25 -year development time, it could be too late to start tackling the patterns of production and consumption that are at the root of the problem." Moreover, "if large volumes of stored $\mathrm{CO}_{2}$ were suddenly to leak, severe climate change would occur without even the limited time we have now for mitigation or adaption" (Diss, Muttitt 2001: 29). One might add that if a large-scale leak from these soon to be established storages appears in a distant future, the result could be a second human-inflicted ecological crisis.

As Oelschlaeger (2001: 221) observes, "the ecosemiotic thesis points toward a watershed event — a paradigm shift — in human selfcomprehension". In a time to come, one might regard this paradigm shift as the start of a new civilization. But a new civilization cannot be brought about through a shift of government, or through a political revolution. What the post-crisis society will look like is hard to imagine in detail, and any ready-made, full-detail vision should be regarded with a great deal of suspicion. Two elements of a new civilization, however, might be a new attitude, or none at all, to property and territory. The idea that the land, beings and resources of this planet belong to man is in my mind not compatible with true morality.

\section{Economic growth}

The seventh point states that there should be a shift from adhering to an increasingly higher standard of living to appreciating life quality. Although I am not sure I agree with Edward Goldsmith (2001), the founder of The Ecologist, that economic growth is no longer an option, I am convinced it is a path we should no longer pursue. Now, one could of course argue - as many have - that the problem is not growth in itself, but its content. However, any sustainable economy i.e., an economy that is compatible with the long-term co-existence of human culture and a richness and diversity of life forms comparable to that of today - has to meet one basic requirement: It must not have further complication of the global ecosystem as a sought, calculated or unexpected consequence. If there can be such a thing as sustainable growth, it will not have much in common with the growth of the 
present economy, nor will it be tied to its logics. It will have to rest on a serious redefinition of the concept of economic growth.

\section{An obligation}

The final point of the deep ecology platform states that those who subscribe to the foregoing points have an obligation directly or indirectly to try to implement the necessary changes. According to Arne Næss, the frontier of the environmental crisis is long and varied, and there is a place for everyone. In this context, biosemiotics and ecosemiotics has a role to play. As Oelschlaeger (2001: 226) notes: "If ecosemiotics is to be more than academic entertainment, then an outline is in order, however provisional or elliptical, of how the ecosemiotic thesis facilitates intentional cultural change".

\section{References}

Brock, Friedrich 1934. Bewegungsphysiologie, Verhaltenspsychologie und Umweltforschung. Verhandlungen der deutschen zoologischen Gesellschaft: 133141.

Bruni, Luis Emilio 2001. Biosemiotics and ecological monitoring. Sign Systems Studies 29(1): 293-312.

Darwin, Charles 1882. The descent of man and selection in relation to sex. London: John Murray.

Diss, Ben; Muttitt, Greg 2001. Carbon injection: An addict's response to climate change. The Ecologist Report 11: 27-27.

Emmeche, Claus 2001. Bioinvasion, globalization, and the contingency of cultural and biological diversity: Some ecosemiotic observations. Sign Systems Studies 29(1): 237-262.

Goldsmith, Edward 2001. A question of survival. The Ecologist Report 11: 46-47. Harrington, Anne 1999. Reenchanted science: Holism in German Culture from Wilhelm II to Hitler. Princeton: Princeton University Press.

Hoffmeyer, Jesper 1993. Biosemiotics and ethics. In: Witoszek, Gulbrandsen 1993: 152-176.

- 1996. Signs of Meaning in the Universe. Bloomington: Indiana University Press.

Kant, Immanuel 1997. Critique of Practical Reason. (Gregor, Mary, trans. and ed.) Cambridge: Cambridge University Press.

Keskpaik, Riste 2001. Towards a semiotic definition of trash. Sign Systems Studies 29(1): 313-324.

Kull, Kalevi 2001. Biosemiotics and the problem of intrinsic value of nature. Sign Systems Studies 29(1): 353-365. 
Kvaløy Sætreng, Sigmund 1993. Complexity and time: Breaking the pyramids reign. In: Reed, Rothenberg 1993: 116-119.

Nöth, Winfried 2001. Ecosemiotics and the semiotics of nature. Sign Systems Studies 29(1): 71-82.

Næss, Arne 1936. Erkenntnis und wissenschaftliches Verhalten. Oslo: Det norske videnskaps-akademi i Oslo.

- 1985. Identification as a source of deep ecological attitudes. In: Tobias, Michael (ed.), Deep Ecology. San Diego: Avant Books, 256-270.

- 1989. Ecology, Community and Lifestyle: Outline of an Ecosophy. (Rothenberg, David, trans. and revised.) Cambridge: Cambridge University Press.

- 1990. Man apart and Deep Ecology: A reply to Reed. Environmental Ethics 12: $185-192$.

- 1993. The deep ecological movement: Some philosophical aspects. In: Zimmerman, Michael (ed.), Environmental Philosophy: From Animal Rights to Radical Ecology. Englewood Cliffs: Prentice Hall, 193-212.

Oelschlaeger, Max 2001. Ecosemiotics and the sustainability transition. Sign Systems Studies 29(1): 219-236.

Pobojewska, Aldona 1993a. Die Subjektlehre Jacob von Uexkülls. Sudhoffs Archiv 77, 54-71.

- 1993b. Die Umweltkonzeption Jacob von Uexkülls: Eine neue Idee des Untersuchungsgegenstandes von der Wissenschaft. In: Lenk, H.; Poser, H. (eds.), Neue Realitäten: Herausforderung der Philosophie (XVI. Deutscher Kongreß für Philosophie, Sektionsbeiträge), Berlin, 94-101.

Reed, Peter; Rothenberg, David (eds.) 1993. Wisdom in the Open Air: The Norwegian Roots of Deep Ecology. Minneapolis: University of Minnesota Press.

Roepstorff, Andreas 2001. Thinking with animals. Sign Systems Studies 29(1): 203-218.

Spinoza, Benedict 1951. Ethics. (Elwes, R. H. M., trans.) New York: Dover.

Tønnessen, Morten 2001. Outline of an Uexküllian bio-ontology. Sign Systems Studies 29(2): 683-691.

- 2002. Umwelt-forskning og ontologi: Skisse av en bio-ontologi basert på Jakob von Uexkülls Umwelt-loere. Oslo: University of Oslo.

Uexküll, Jakob von 1909. Umwelt und Innenwelt der Tiere. Berlin: Verlag von Julius Springer.

- 1910. Über das Unsichtbare in der Natur. Österreichische Rundschau 25: 124-130.

- 1917. Darwin und die englische Moral. Deutsche Rundschau 173: 215-242.

- 1920a. Theoretische Biologie. Berlin: Verlag von Gebrüder Paetel.

- 1920b. Staatsbiologie: Anatomie - Physiologie - Pathologie des Staates. Special edition of Deutsche Rundschau. Berlin: Verlag von Gebrüder Paetel.

- 1921. Umwelt und Innenwelt der Tiere. (2nd ed.) Berlin: Verlag von Julius Springer.

- 1922. Wie sehen wir die Natur und wie sieht sie sich selber? Die Naturwissenschaften 10(12-14): 265-271, 296-301, 316-322.

- 1926. Theoretical Biology. (MacKinnon, D. L., trans.) London: Kegan Paul.

- 1928. Theoretische Biologie. 2te Aufl. Berlin: J. Springer. 
- 1980. Kompositionslehre der Natur. Biologie als undogmatische Naturwissenschaft. Ausgewählte Schriften. (Uexküll, Thure von, ed.). Frankfurt am Main: Verlag Ullstein GmbH.

- 1982. The theory of meaning. Semiotica 42(1): 25-82. [Stone, Barry; Weiner, Herbert, trans.]

- 1992 [1957]. A stroll through the worlds of animals and men: A picture book of invisible worlds. [Schiller, Claire H., trans.] Semiotica 89(4): 319-391.

Uexküll, Jakob von; Kriszat, Georg 1956. Streifzüge durch die Umwelten von Tieren und Menschen: Ein Bilderbuch unsichtbarer Welten [1934]. Bedeutungslehre [1940]. [Text by Uexküll, illustrations by Kriszat.] Hamburg: Rowohlt.

Uexküll, Thure von 1992. Introduction: The sign theory of Jakob von Uexküll. Semiotica 89(4): 279-315.

Wetlesen, Jon 1993. Who has a moral status in the environment? In: Witoszek, Gulbrandsen, 1993: 98-129.

Witoszek, Nina; Gulbrandsen, Elisabeth (eds.) 1993. Culture and Environment: Interdisciplinary Approaches. Oslo: Centre for Development and the Environment.

\section{Этика умвельта}

В данной статье я пытаюсь начертить принципы этики умвельта, т.е. такой этики, которая бы в своих фундаментальных признаках опиралась на положения теории умвельта Якоба фон Юкскюлла. При интерпретации теории умвельта определяется ряд понятий: онтологическая ниша, общий умвельт, тотальный умвельт, биоонтологическая монада. Во второй части статьи предлагается, исходя из теории Юкскюлла, понимание платформы глубинной экологии. Утверждается, что исчезновение биологического разнообразия (как физио-феноменного свойства) является главным аспектом экологического кризиса, и что это можно рассматривать как онтологический кризис.

\section{Omailma eetika}

Artiklis püütakse visandada niisuguse eetika põhimõtted, mis olulisel määral tugineks Jakob von Uexkülli omailma teooria seisukohtadele. Omailma teooria tõlgendamisel määratletakse rida mõisteid: ontoloogiline nišš, ühine omailm, totaalne omailm, bio-ontoloogiline monaad. Artikli teises osas esitatakse süvaökoloogia platvormi tõlgendus Uexkülli vaatekohast lähtudes. Väidetakse, et bioloogilise mitmekesisuse (kui füsiofenomeense omaduse) kadu on ökokriisi kõige peamisem aspekt, ning seda tuleb mõista kui ontoloogilist kriisi. 